\title{
Sikkerhetspolitisk minnediplomati: Opprettelsen av Frigjøringsmonumentet i Kirkenes 1945-1952
}

\author{
Joakim Aalmen Markussen \\ Narviksenteret, Norge
}

\begin{abstract}
Security Policy and Memory Politics: Establishing the Soviet Liberation Monument in Kirkenes, 1945-1952

A few kilometers from the border with Russia, in the town of Kirkenes in the easternmost corner of Northern Norway, there stands a bronze statue of a Soviet soldier looking out over the borderland. The Soviet Liberation Monument, as the statue is called, was unveiled in 1952 by the Norwegian authorities, in gratitude for the Soviet liberation of the East Finnmark area in 1944. The statue has served as a meeting place for regular commemorative ceremonies involving the Norwegian and Soviet authorities, throughout the Cold War and up until the present. This article explores the interplay between security policy and memory politics at the onset of the Cold War by examining the seven-year long process of establishing this monument. As the Iron Curtain descended over Europe, the monument and the memories attached to it became important tools with which Norway developed a critical dialogue with its great-power neighbor. The article shows how the Norwegian Ministry of Foreign Affairs learned how to use the collective memories of the Soviet liberation to ensure Norway's security-policy goal of low tension in its relations with the USSR.
\end{abstract}

Keywords: memory politics, Cold War, Norway, Soviet Union, liberation, monument

På Haganeshaugen i Kirkenes, byens høyeste punkt, står en to og en halv meter høy bronsestatue på granittsokkel. Statuen framstiller en uniformert sovjetisk soldat som skuer utover området med en maskinpistol i hendene. Med den ene foten hvilende på en stein litt foran den andre, ser det ut som soldaten vurderer veien videre $\mathrm{i}$ det åpne landskapet. Frigjøringsmonumentet, eller Russermonumentet som statuen kalles på folkemunne i Sør-Varanger, ble reist av norske myndigheter til minne om «Sovjetsamveldets tapre soldater» som frigjorde Kirkenes i $1944 .^{1}$

\footnotetext{
${ }^{1}$ Inskripsjonen på monumentet, slik det står i dag, lyder "Til Sovjetsamveldets tapre soldater til minne om Frigjøringen av Kirkenes 1944.»
}

Kontaktinformasjon: Joakim Aalmen Markussen, e-post: jam@narviksenteret.no 
Monumentet er spesielt på flere måter. Det ble avduket tre år etter at Norge hadde tatt Nato og USAs side mot Sovjetunionen i den kalde krigen. I tillegg finnes det svært få andre eksempler på at det ble opprettet monumenter til minne om Den røde armés innsats utenfor Warzawapakt-landene. De mest kjente er plassert i Tiergarten i den britiske sonen av Vest-Berlin, og på Schwarzenbergplatz i Wien. Begge ble avduket i 1945, og med en høyde opp mot tjue meter framstår de som tydelige seiersmonumenter. Til sammenligning er Frigiøringsmonumentet i Kirkenes totalt 5,5 meter høyt. På samme måte som i Kirkenes kom også disse i stand etter initiativ fra Sovjetunionen, men både i Wien og i Berlin hadde sovjetiske myndigheter eneansvar for å utforme minnestedene. Symbolikken er derfor annerledes - i Berlin utgjør for eksempel både artillerikanoner og stridsvogner en del av monumentet (Gegner, 2012). Enda en forskjell er at det i Kirkenes ikke kommer fram av monumentet hvem Den røde armé kjempet mot, mens inskripsjonene ved monumentene $\mathrm{i}$ Wien og i Berlin viser til Den røde armés kamp for å frigjøre Sovjetunionen fra de "tyske fascistiske okkupanter» (Zhurzhenko, 2018, s. 97).

Frigjøringsmonumentet i Kirkenes ble planlagt i samarbeid mellom norske og sovjetiske myndigheter, og det gjenspeiler enda en sjeldenhet, nemlig at Sovjetunionen trakk seg fredelig og betingelsesløst ut av Finnmark etter at andre verdenskrig var over (Holtsmark, 2015a). Siden 1954, ved tiårsjubileet for frigjøringen av Finnmark, har monumentet hvert femte år - gjennom den kalde krigen og helt fram til i dag - vært åsted for minnemarkeringer med norske og sovjetiske myndigheter til stede (Myklebost \& Markussen, 2021). Frigjøringsmonumentet har fortsatt å være en viktig møteplass, og til tross for Krim-krisa i 2014 deltok de to landenes utenriksministre ved jubileumsmarkeringene i Kirkenes i 2014 og 2019 (Winge, 2019; om Norges forhold til Russland etter 2014, se Rowe, 2018).

I de sju årene fra planene om monumentet ble lansert i 1945 til det ble avduket i 1952, ble utseendet, størrelsen og inskripsionene endret. Flere har hevdet at nedskaleringen og endringene var et bevisst oppgjør med det kommunistiske Sovjetunionen fra norsk side, og et forsøk på å markere Norges tilhørighet til Nato (Folkenborg, 2019; Olsen, 2014). Det er naturlig at den kalde krigen tvang fram endringer i norsk sikkerhetspolitikk, men hvilken rolle spilte Frigjøringsmonumentet i utformingen av Norges diplomatiske forbindelser til Sovjetunionen?

I denne artikkelen vil jeg argumentere for at norske myndigheter i prosessen med å reise Frigjøringsmonumentet førte en diplomatisk minnepolitikk som åpnet for en kritisk dialog med Sovjetunionen (Bones, 2006; Tjelmeland, 2017). Som jeg vil komme tilbake til senere, førte arbeidet med Frigiøringsmonumentet til at det ble etablert et pustehull i jernteppet som senket seg over Europa i løpet av årene 1945-1952. I den lange prosessen med å reise Frigjøringsmonumentet la norske myndigheter grunnlaget for hvordan minnene om den sovjetiske frigiøringen kunne brukes til å sørge for lavspenning i forholdet med Sovjetunionen. 


\section{Sikkerhetspolitikk og kollektive minner}

Erfaringer fra fortiden spiller en sentral rolle i utformingen av et lands sikkerhetspolitikk (Mälksoo, 2015). Erfaringene fra andre verdenskrig spilte for eksempel en viktig rolle for Norges nye alliansepolitikk etter 1945 (Hilde, 2019). I denne artikkelen vil jeg betegne de fortidige erfaringene som kollektive minner. Det er et komplekst begrep som stammer fra forskningsfeltet minnestudier (se f.eks Tamm, 2013). Noe forenklet kan kollektive minner beskrives som en fortelling om fortidige hendelser. Denne fortellingen skapes, opprettholdes og endres av sosiale fellesskap, og den består av langt mer enn det som finnes mellom to permer i en historiebok (se f.eks. Olick \& Robbins, 1998). Det sosiale fellesskapet kan være familier, lokalsamfunn, menings- og verdifellesskap, eller det kan være avgrenset av større og mer heterogene kjennetegn som for eksempel religiøs overbevisning eller nasjonal tilhørighet (Erll \& Young, 2011).

Det sosiale fellesskapet skaper et bilde av fortiden som passer med dets nåtidige interesser, selvbilde og ambisjoner for fremtiden, og det er dette som utgiør støpeskjeen for kollektive minner (Erll \& Young, 2011; Winter, 2006). Ved utvelgelse av spesielle elementer fra fortiden skapes det narrativet som ses som best egnet til å tjene fellesskapets ambisjoner. Selve utvelgelsen giøres av det som Aleida Assmann har betegnet som minnespesialister - handlende aktører som giør noe for å formidle utvalgte perspektiver på fortiden (Assmann, 2006; Erll \& Young, 2011). I denne artikkelen vil fokuset ligge på hvordan norske myndigheter, og først og fremst Utenriksdepartementet (UD), framstilte den sovjetiske frigiøringen. UD ble, blant annet på grunn av sitt ansvar for arbeidet med Frigjøringsmonumentet, den viktigste aktøren i etableringen av det vi kan kalle det offisielle norske minnet om den sovjetiske frigjøringen av Finnmark i årene fra 1945-1952 (for mer om nasjonale minner, se f.eks. Poole, 2008). Ved at sovjetiske aktører gikk i dialog med nordmennene om hvordan frigjøringen skulle minnes, ble det kollektive minnet som UD etablerte i disse årene ikke bare formet av rent norske hensyn, men også av sovjetiske interesser. Det kollektive norske minnet ble dermed formet av et minnediplomati som utviklet seg mellom Norge og Sovjetunionen.

Selv om det er en sammenheng mellom sikkerhetspolitikk og kollektive minner, er den ikke alltid innlysende, og det er sjelden mulig å dokumentere at aktørene som former sikkerhetspolitikken er bevisste på hvordan de kollektive minnene virker inn på deres arbeid. Enda vanskeligere er det å slå fast at aktørene er oppmerksomme på hva de gjør når kollektive minner brukes til å oppnå sikkerhetspolitiske mål. Det er som regel enklere å identifisere hvordan dagsaktuelle politiske hensyn vurderes av aktørene. Paal Sigurd Hilde treffer for eksempel godt når han skriver at norsk sikkerhetspolitikk etter andre verdenskrig ble formet «i skjæringspunktet mellom behovet for støtte fra vest, lavspenning med øst og innenrikspolitiske hensyn» (Hilde, 2019, s. 61). Men inn i denne prosessen virket også de kollektive minnene, spesielt når det kom til å sikre lavspenning med Sovjetunionen. Å fortrenge minnene om den 
sovjetiske frigjøringen kunne få konsekvenser for det bilaterale forholdet til Sovjetunionen, mens en for sterk hyllest av Den røde armés innsats ville ta seg dårlig ut blant Norges allierte i Nato.

Disse overlappende hensynene, og spørsmålene om hvordan de skulle prioriteres, dannet bakteppet for Norges forhold til både Nato og Sovjetunionen forhold som senere i den kalde krigen ble kjennetegnet av begrepsparene integrasjon/ avskjerming overfor Nato (Tamnes, 1987, s. 37), og beroligelse/avskrekking overfor Sovjetunionen (Holst, 1967, s. 31-35). Det må kunne sies at den norske sikkerhetspolitikken var vellykket. Relasjonene mellom Norge og Sovjetunionen - og etter 1991, Russland - har i hovedsak vært vennskapelige og preget av samarbeid. I det minste har det vært et felles ønske om dialog (for en gjennomgang av forholdet mellom Norge og Sovjetunionen/Russland, se Holtsmark, 2015e). Det har likevel vært flere, og tidvis sterke innslag av mistenksomhet fra begge sider.

I tiden etter at Frigjøringsmonumentet ble avduket, har det imidlertid ikke vært noen kontroverser om selve monumentet - heller ikke etter Sovjetunionens fall i 1991. Det gjør at Frigjøringsmonumentet er ganske særegent i europeisk sammenheng. I den post-sovjetiske perioden har monumenter og statuer til minne om Den røde armés innsats vært gjenstand for flere kontroverser i en rekke tidligere sovjetrepublikker i Sentral- og Øst-Europa (se f.eks. Ehala, 2009; Gabowitsch, 2014; Kalashnikov, 2018; Kriza, 2018; Stangl, 2010). De siste tiårenes minnepolitiske konflikter knyttet til sovjetiske krigsminnesmerker har blitt betegnet som en minnekrig en konflikt mellom Russland og de tidligere sovjetrepublikkene om Den røde armés krigsinnsats skal framstilles som en frigjøring fra tysk okkupasjon eller starten på en sovjetisk okkupasjon (Koposov, 2018; Miller, 2020; Torbakov, 2011). Tradisjonen for felles minnemarkeringer som ble etablert ved avdukingen av Frigjøringsmonumentet i 1952 har derimot fortsatt uavbrutt helt frem til i dag, og diplomati har i stedet kjennetegnet de minnepolitiske relasjonene mellom Norge og Sovjetunionen/ Russland helt fra avdukingen.

Den grunnleggende forklaringen på at Frigjøringsmonumentet skiller seg fra situasjonen i Øst-Europa ligger først og fremst i at Norge ikke ble okkupert av Den røde armé på samme måte som de tidligere sovjetrepublikkene. Norge var i stedet ett av svært få eksempler på at de sovjetiske frigjørerne faktisk var frigjørere; de drev tyskerne vekk, bisto sivilbefolkningen med forsyninger og hjelp, og de trakk seg ut og overlot området til Norge da situasjonen var under kontroll igjen. I denne artikkelen vil jeg argumentere for at Norge og Sovjetunionen utviklet en felles overenskomst om hvordan historien skulle brukes, og hva den skulle brukes til, allerede i prosessen med å reise monumentet. Å bruke fortiden til å skape samhold og stabilitet blant mennesker i sosiale fellesskap faller inn under det Klas Göran Karlsson har betegnet som eksistensiell historiebruk (Karlsson, 2004). Uten at vi kan vite sikkert om aktørene var bevisste på hvordan de brukte historien der og da, førte arbeidet med å reise Frigjøringsmonumentet - som vi skal se senere - til at det ble etablert et offisielt norsk kollektivt minne om den sovjetiske frigjøringen 
som ga rom for å ivareta Norges relasjoner til både Sovjetunionen og Nato-allierte inn i den kalde krigen.

Materialet til denne artikkelen stammer fra Kirke- og undervisningsdepartementet og Utenriksdepartementet, og har vært lite brukt i tidligere forskning på temaet. Arkivmaterialet fra begge departementer er omfangsrikt, og består blant annet av interne notater, møtereferater og korrespondanse mellom de ulike aktørene som var involverte i arbeidet med å reise Frigjøringsmonumentet. Materialet viser at prosessen med å reise Frigjøringsmonumentet var en av de første prøvene den norske balansepolitikken ble satt på, men også at norske myndigheter i perioden 1945-1952 arbeidet aktivt for å etablere en ukontroversiell arena for dialog med Sovjetunionen. Samtidig kommer det fram at UD underveis lærte seg å bruke Frigjøringsmonumentet og de kollektive minnene om Den røde armés innsats til å tjene et sikkerhetspolitisk mål - nemlig lavspenning i forholdet til Sovjetunionen. Både minnepolitikk og sikkerhetspolitikk ble i denne perioden et felt for utøvelse av diplomati.

\section{Frigjøringsmonumentet i Kirkenes - et uttrykk for brobyggingspolitikk?}

Forslaget om å reise et monument til minne om de sovjetiske soldatene som hadde falt under frigjøringen av Kirkenes-området i 1944, ble lagt frem av sovjetiske militære myndigheter allerede våren 1945 (Aas, 2012). Distriktskommandoen i Finnmark mente da at de sovjetiske skissene til monumentet "gjør et godt inntrykk». ${ }^{2}$ I de første sovjetiske tegningene skulle monumentet være 13 meter høyt, men det er ingenting $\mathrm{i}$ arkivmaterialet som tyder på at dimensjonene vakte reaksjoner på norsk side (Aas, 2012). Arbeidet ble tvert imot startet med stor interesse, og den norske regjeringen vedtok å samarbeide med Sovjetunionen om å etablere monumentet. I slutten av juli 1945 møttes de to landenes representanter i Kirkenes for å diskutere det videre arbeidet. I forkant av dette møtet hadde den norske ambassaden i Moskva anbefalt departementet at «man svarer russerne at nordmennene setter stor pris på den vakre tanken men at det i sin tid vil bli et norsk privilegium å sette opp et monument av den påtenkte art». ${ }^{3}$

Den norske interessen for å reise Frigjøringsmonumentet hang sammen med samarbeidet mellom landene under krigen. Norske myndigheter hadde i 1944 arbeidet med å få på plass en bilateral avtale som skulle regulere samarbeidet dersom Sovjetunionen skulle komme til å rykke inn på norsk territorium (Holtsmark, 2015d).

\footnotetext{
${ }^{2}$ DKF til FO II, 15.5.1945, Riksarkivet, Utenriksdepartementet (ref. S-2259 på Riksarkivet), serie DyD, stykke L10082, mappe Doss 8.6.15 Bd 1 (heretter RA/S-2259/Dyd/L10082/Doss 8.6.15 Bd. 1).

${ }^{3}$ Vogt til Nygaardsvold, 2.7.1945, Riksarkivet, Kirke- og undervisningsdepartementet, 1. skolekontor D (ref. S-1021 på Riksarkivet), serie E Ej, stykke L0700, mappe 0004 Kirkenesmonumentet for frigjøringen (heretter RA/S-1021/E/Ej/L0700/0004). Forfatterens kursivering.
} 
Etter den sovjetiske innmarsjen i Finnmark i oktober 1944, og frem til freden i mai 1945 hadde det vært et nært og tillitsfullt samarbeid mellom norske og sovjetiske myndigheter (Holtsmark, 2015a; se også Lippe, 1964). De gode erfaringene fra den siste krigsvinteren la noe av grunnlaget for den norske brobyggingspolitikken de første årene etter 1945 (Tjelmeland, 2015).

Da Norge offentliggjorde planene om å reise monumentet i juli 1945, ble det annonsert at arbeidet ble startet «med like stor interesse av de norske som de sovjetrussiske myndigheter». Kirke- og undervisningsminister Kaare Fostervold uttalte i Verdens Gang (VG) at de norske "sakkyndige er meget tilfredse med utkastet». Billedhugger Stinius Fredriksen, som hadde fått i oppdrag å lage monumentet, sa at han "synes det ser meget bra ut» (Verdens Gang, 1945a).

Den sovjetiske siden ønsket opprinnelig at statuen skulle oppføres på torget midt i Kirkenes, med en 10 meter høy sokkel. Fra norsk hold bestemte man etter litt nøling at monumentet skulle plasseres noe mindre sentralt, på en høyde over byens tilfluktsrom i et boligområde. Den 18. juli 1945 ble tomten til monumentet stukket ut og markert på Haganeshaugen i Kirkenes. I august 1945 sendte Kirkedepartementet arkitekt Gudolf Blakstad og billedhugger Stinius Fredriksen til Kirkenes for å diskutere saken med sovjetiske militære myndigheter. Et halvoffisielt møte fant sted med den norske Kronprins Olav til stede. Her avtalte man en arbeidsfordeling; den sovjetiske siden skulle planere tomten og utforme en statue av en sovjetisk soldat $\mathrm{i}$ bronse og frakte den til Kirkenes. Den norske siden fikk ansvar for å skaffe stein til sokkelen (Verdens Gang, 1945b, 1945c). Da de sovjetiske styrkene trakk seg ut av Finnmark høsten 1945, var det imidlertid uten å ha startet arbeidet på tomta. Hvis planene om monumentet skulle realiseres, var det nå opp til Norge å ta seg av alt arbeid og alle kostnader.

Historien om Frigjøringsmonumentet kunne stoppet der. Det eksisterte kun på tegnebrettet, og den omfattende oppgaven med å gjenreise bebyggelsen etter tyskernes ødeleggelser ville giøre det mulig å forsvare å avlyse byggingen av monumentet. Slike tanker ble imidlertid ikke luftet i 1945, for i Norge hersket det stor begeistring for Sovjetunionens krigsinnsats (Holtsmark, 2015b). At norske myndigheter valgte å fortsette arbeidet vitner om et genuint ønske om å hedre stormaktsnaboen i øst det var i tråd med den norske brobyggingspolitikken å sørge for et godt forhold til Sovjetunionen. Også lokalt var interessen for monumentet stort, og Sør-Varanger kommune erklærte raskt at de var «villig til å påta seg utførelsen av det arbeide som russerne hadde ment å utføre». ${ }^{4}$ Heller ikke det norske Finansdepartementet hadde «noe å innvende mot at det blir søkt samtykke [...] til straks å nytte ytterligere kr. 50.000 til oppføring av et monument for den røde arme i Kirkenes». ${ }^{5}$

\footnotetext{
${ }^{4}$ Kirkedepartementet til UD, 18.9.1946, RA/S-2259/Dyd/L10082/Doss 8.6.15 Bd.1.

${ }^{5}$ Henriksen til Kirkedepartementet, 11.12.1945, RA/S-1021/E/Ej/L0700/0004.
} 
Til tross for norsk iver etter å realisere Frigjøringsmonumentet, gikk arbeidet sakte etter at tomten ble markert i terrenget. I mellomtiden gjorde norske myndigheter de første endringene på monumentet. Det ble bestemt at sokkelen skulle halveres til fem meter, slik at monumentet ikke ruvet i bybildet. Og mens man fra sovjetisk side hadde foreslått at avdukingen skulle foregå på 30-årsdagen for den russiske revolusjon, 7 . november 1947, utsatte Norge starten på byggeprosessen i flere runder. De norske utsettelsene kan ses som uttrykk for den gradvise sikkerhetspolitiske orienteringen mot vest i de umiddelbare etterkrigsårene, som ble endelig befestet med norsk Nato-medlemskap i 1949. I arkivmaterialet er det imidlertid materialmangelen og det ekstraordinære behovet for å gjenreise den ødelagte bebyggelsen som anføres som årsak til at byggingen av monumentet måtte utsettes.

\section{Nye trusselbilder}

I løpet av de årene Frigjøringsmonumentet ble nedprioritert, skjedde det store endringer i internasjonal politikk. I 1947 ble forholdet mellom USA og Sovjetunionen stadig mer anstrengt, og på grunn av sin "«strategiske beliggenhet»» ble Norge mer og mer presset av de to stormaktene (Holtsmark, 2015b, s. 286). Etter først å ha forsøkt å være brobygger mellom øst og vest, økte etter hvert de norske bekymringene for Sovjetunionens ambisjoner for Nord-Norge spesielt, og Norge generelt (Holtsmark, 2015b). I det nye trusselbildet dukket erfaringene fra 9. april og den mislykkede nøytralitetslinjen i 1940 opp for alvor (Holtsmark, 2015c). Parolen om aldri mer 9. april illustrerte at tiden var kommet for en mer aktiv norsk alliansepolitikk.

Dermed var det andre kollektive minner som ble aktualisert når nye trusselbilder begynte å ta form: Når Norge ikke hadde hatt kapasitet til å stå imot Tyskland under verdenskrigen, var det bred politisk enighet om at Norge ville trenge hjelp fra allierte for å motstå et eventuelt sovjetisk angrep (Hilde, 2019; Skogrand, 2004). Parallelt økte den norske bekymringen for sovjetiske ambisjoner, blant annet på grunn av Svalbard-saken. I 1944, i det som ellers hadde vært et godt samarbeidsklima, hadde sovjetiske myndigheter foreslått at Norge og Sovjetunionen skulle dele ansvaret for Svalbard, mens Bjørnøya skulle havne under sovjetisk suverenitet.

Forslaget ble oppfattet som et krav, og vakte mye mistenksomhet på norsk side. Likevel ble det ikke snakk om noen komplett avvisning. Norge sa seg villig til å møtes for å diskutere spørsmålet med Sovjetunionen. Det kom ikke noe svar fra sovjetisk side, og saken dro ut. I 1947 luftet Sovjetunionen spørsmålet på nytt, men da konkluderte regjeringen med å avslå «å ta opp drøftelser av militær art om forsvaret av et område under norsk suverenitet med en enkelt annen makt» (Holtsmark, 2015b, s. 301-302). Norges avvisning av det sovjetiske kravet fikk ikke noe videre etterspill, og historiker Sven Holtsmark forklarer det med at sovjetiske myndigheter ikke ville risikere at mer press på saken skulle medføre at Norge søkte tettere forbindelser med vestmaktene (Holtsmark, 2015b, s. 302). 
I Europa begynte det samtidig å tegne seg tydeligere linjer mellom blokkene. I 1948 signerte Finland en bilateral vennskap-, samarbeids- og støttepakt med Sovjetunionen, og norske myndigheter fikk signaler om at Sovjetunionen ønsket det samme for Norge (Holtsmark, 2015c). Tidligere samme år hadde kommunistene ryddet opposisjonen unna i Tsjekkoslovakia (Holtsmark, 2015c). Disse hendelsene gjorde at Sovjetunionen begynte å fremstå stadig mer som en trussel. Minnene om at Sovjetunionen hadde vært den eneste av Norges allierte til å aktivt frigjøre norsk territorium - og det i overenstemmelse med en bilateral avtale - druknet i bekymringen om hva Norge skulle giøre for å forhindre å havne under en ny okkupasjon.

Etter at forsøkene på å få i stand en skandinavisk forsvarsallianse kollapset i 1949, sendte Norge forespørsler til Storbritannia og USA om de kunne gi en forpliktende garanti for at Norge ville motta hjelp i tilfelle krig. Kort tid etter ble Atlanterhavspakten realisert, og i april 1949, etter først å ha forsikret seg om at norsk medlemskap ikke ville framprovosere sovjetiske reaksjoner, signerte Norge avtalen (Holtsmark, 2015c). Til tross for norsk medlemskap i Nato forsøkte Norge fortsatt å balansere sin posisjon mellom stormaktene, noe den norske baseerklæringen var et tydelig uttrykk for. Den slo fast at Norge ikke ville tillate permanent utstasjonering av allierte styrker i Norge i fredstid (Holtsmark, 2015c). Basepolitikken var en selvpålagt restriksjon, og et grep som skulle forsikre at Norge ikke skulle bli et oppmarsjområde for et Nato-angrep på Sovjetunionen. På den ene siden var det altså fremdeles et mål å beholde lavspenning i forholdet til Sovjetunionen, og på den andre siden skulle Nato sørge for å avskrekke potensielle sovjetiske ambisjoner overfor Norge.

Man kunne kanskje tenke seg at den sikkerhetspolitiske kursendringen og den norske vestvendingen ville resultere $i$ at planene om Frigjøringsmonumentet i Kirkenes ble skrinlagt. Det var flere oppgjør med grupper som av norske myndigheter ble sett på som sympatiserende overfor Sovjetunionen og kommunismen. Statsminister Einar Gerhardsens tale på Kråkerøy, der han erklærte kommunismen for å være en trussel mot det norske demokratiet, var et tydelig uttrykk for at verken kommunister eller kommunisme var ønsket i Norge (Eriksen, 1972). Det er imidlertid ingenting $\mathrm{i}$ arkivmaterialet som gir inntrykk av at byggingen av Frigjøringsmonumentet i Kirkenes ble vurdert avbrutt eller avlyst på grunn av Nato-medlemskapet. I starten av februar 1950 gav for eksempel Utenriksdepartementet beskjed om at billedhugger Fredriksen skulle kontakte den sovjetiske ambassaden for å få hjelp til å oversette et sitat av Stalin som skulle stå på monumentet. ${ }^{6}$ Selv om det er uklart hvor lenge departementet hadde vært kjent med teksten, er det på dette tidspunktet ingen spor i arkivmaterialet av norske reaksjoner på at et sitat av Stalin skulle gjengis på monumentet.

${ }^{6}$ Finne-Grønn til Kirkedepartementet, 6.2.1950, RA/S-1021/E/Ej/L0700/0004. 


\section{Kontroversielle endringer}

Friheten, partiavisa til Norges kommunistparti, var de første til å formidle at avdukingen av statuen skulle skje i løpet av sommeren 1951. Det var utfordringer som «sementmangel og mangel på arbeidskraft» som lå bak de mange forsinkelsene, skrev avisa (Friheten, 1951). Da sommeren nærmet seg, dukket det for første gang opp innsigelser mot monumentets utseende og symbolikk. Der de sovjetiske skissene hadde blitt akseptert uten innvendinger i 1945, ble det stilt flere ubehagelige spørsmål da monumentets utseende ble offentlig kjent i juni 1951. Det var Morgenbladet som først skrev at monumentet skulle avbilde «en to og en halv meter høy russisk soldat med stengun som tramper på den overvunne tyske ørn». ${ }^{7}$ Morgenbladet kommenterte også at det "overdimensjonerte seiersmonumentet til ære for 'den heltemodige røde armé' som det skal stå på sokkelen, forekommer mange å falle noe utenfor rammen av hva vi er vant til her i landet» (Morgenbladet, 1951).

Det var ikke bare størrelsen på monumentet som gradvis ble mer problematisk. Da Norge i 1951 opprettet diplomatiske kontakter med Vest-Tyskland og arbeidet for et vesttysk Nato-medlemskap, gikk arbeidet med Frigjøringsmonumentet inn i en ny fase. I de sovjetiske tegningene lå det, som nevnt tidligere, opprinnelig en ørn med utbredte vinger under soldatens ene fot - et symbol på Den røde armés seier over det nazistiske Tyskland. Problemet var at Vest-Tyskland hadde tatt i bruk en variant av den tradisjonelle tyske ørna i sitt offisielle flagg.

Den sterkt samfunnsengasjerte og profilerte norske psykiateren Johan Scharffenberg skrev i Morgenbladet at de «fleste tyskere, uansett parti, vil føle et sånt minnesmerke som en fornærmelse». Han mente det var «kortsynt av den norske regjering å reise et monument som håner den tyske ørn» fordi «Tyskland vil igjen arbeide seg opp til stormakt». Han trakk samtidig inn det nye forholdet Norge hadde fått til Sovjetunionen: «Den i 1945 trufne avtale mellom Norge og Sovjet-Russland om monumentet skyldtes den darådende innstilling. Senere er forholdet radikalt endret» (Scharffenberg, 1951). Det var ikke Tyskland i seg selv Norge burde markere seieren over, men det nazistiske regimet, mente Scharffenberg.

Noen dager senere ble monumentet tema for en regjeringskonferanse. Under møtet ble det gjort en rekke beslutninger som skulle komme til å få stor innvirkning på det offisielle minnet om den sovjetiske frigjøringen av Øst-Finnmark. En av regjeringens beslutninger var at "den tyske ørn om mulig ble erstattet med hakekorset [...] eller eventuelt fjernet». ${ }^{8}$ I tillegg skulle størrelsen på monumentet nedjusteres. Til slutt ble det også bestemt at inskripsjonene på monumentet skulle endres. Det var opprinnelig meningen at den ene inskripsionen skulle være en dagsbefaling av Josef Stalin. Sitatet lød:

\footnotetext{
${ }^{7}$ Statuen skulle holde en russisk maskinpistol, men det virker som om stengun ble brukt som samlebegrep for alle typer maskinpistoler.

${ }^{8}$ Utenriksdepartementet til Kirkedepartementet, 23.6.1951, RA/S-1021/E/Ej/L0700/0004.
} 
Vi har ikke og kan ikke ha slike krigsmål som å tvinge vår vilje og vårt regime inn på de slaviske og andre trellbundne folk i Europa, som venter hjelp av oss. Vårt mål består i å hjelpe disse folk i deres frihetskamp mot Hitlertyranniet og deretter overlate til dem selv å innrette seg helt fritt på sin jord slik som de vil. ${ }^{9}$

Den andre inskripsjonen skulle opprinnelig lyde: «Til den heltemodige Røde Armé som har frigjort Kirkenes fra de tyske fascistiske okkupanter den 25. oktober 1944». ${ }^{10}$ Teksten på disse inskripsjonene ble drøftet av Utenriksdepartementet våren 1951. Departementet mente at «en enklere inskripsjon ville være mer passende» og foreslo å fjerne sitatet fra Stalin, og heller la følgende tekst stå på norsk og på russisk: «Til Sovjetsamveldets tapre soldater til minne om frigjøringen av Kirkenes $1944 » .{ }^{11}$ Dette var betydningsfulle endringer. Monumentet og minnesmerket skulle begrenses til å hedre minnet om de som frigjorde Kirkenes som en isolert operasjon, ikke som en del av frigjøringen av Europa, slik Stalins sitat ga inntrykk av. Omtalen av «de tyske fascistiske okkupanter» ble også fjernet. I tillegg skulle fiendens symboler, representert ved nazi-ørna, heller ikke være synlige.

Det har vært hevdet at billedhugger Fredriksen protesterte mot fjerningen av den tyske ørna, og at han betegnet det som en "amputasjon» (Olsen, 2014). I et brev til Kirke- og undervisningsdepartementet den 28. juni 1951 skrev han imidlertid at det «ikke er noen tekniske vanskeligheter med å fjerne ørnen på bronseskulpturen. Det går nemlig et skjøt i støpningen». Han skrev videre at han selv var «villig til å være behjelpelig med eventuelle skisser [til] hvordan det best kan giøres». ${ }^{12}$ Hva Fredriksen privat måtte ha ment om beslutningen, kommer ikke fram i arkivmaterialet. Derimot er det tydelig av materialet at UDs målsetning med å fjerne den anti-tyske symbolikken som nazi-ørna representerte, først og fremst var et forsøk på å unngå å håne Vest-Tyskland, ikke å skyggelegge Sovjetunionens innsats. Endringene, og ikke minst den nye inskripsjonen, medførte like fullt at statuen kom til å dreie seg om de sovjetiske soldatene som hadde falt ved Kirkenes. Selve frigiøringen ble dermed erklært å ha begrenset seg til Kirkenes og Øst-Finnmark, og monumentet var taust om hvem de sovjetiske soldatene hadde kjempet mot.

\section{Sovjetiske reaksjoner}

Under tittelen «Seiersmonumentet blir 'dempet ned', skrev VG i slutten av august 1951 at «den tyske ørn som den russiske soldaten tråkker på [er] tatt bort». I utklippet av VGs notis, som ligger i UDs arkiv, har noen understreket «dempet ned» og

\footnotetext{
${ }^{9}$ Notat, 19.5.1951, RA/S-2259/Dz/L0484/Doss 8.6.15, Bd. II. Gitt Sovjetunionens behandling av Polen og Tsjekkoslovakia, var teksten noe paradoksal.

${ }^{10}$ Notat, 19.5.1951, RA/S-2259/Dz/L0484/Doss 8.6.15, Bd. II.

${ }_{11}$ «Monument til minne om frigjøringen av Finnmark», udatert, RA/S-2259/Dz/L0484/Doss 8.6.15, Bd. II.

${ }^{12}$ Fredriksen til Kirkedepartementet, 28.6.1951, RA/S-1021/E/Ej/L0700/0004.
} 
med penn i margen kommentert at «[d]ette var et uheldig uttrykk». ${ }^{13}$ UD var tilsynelatende forberedt på at endringene ville vekke reaksjoner, og i kontroversen som fulgte ble Norges minnepolitikk brukt som et vikarierende mål for sovjetiske propaganda-angrep på norsk sikkerhetspolitikk.

Den norske ambassaden i Moskva rapporterte at den sovjetiske avisen Izvestija hadde publisert en artikkel med overskriften «Norske myndigheter håner sovjetiske soldaters minne». Ifølge artikkelen skulle de "ledende kretser i landet [helst se] at beslutningen om å reise minnesmerket ble glemt». Dette føyde seg, ifølge den sovjetiske avisa, inn i rekken av andre tilfeller der norske myndigheter hånte minnet om den sovjetiske krigsinnsatsen: "Avisen omtaler de pietetsløse former som overføringen [av levningene av falne sovjetiske fanger i Norge] skjer under og hevder at myndighetene ønsker å viske ut minnene etter det norske folks frigjørere». ${ }^{14}$ Selv om monumentet ville være klart til avduking senhøsten 1951, mente departementet at det ville «neppe være heldig å foreta avdukingen akkurat nu når vi har striden om krigsgravene gående». ${ }^{15}$

Striden om krigsgravene dreide seg om de sovjetiske krigsfangene som hadde omkommet eller blitt drept og deretter gravlagt i Norge under verdenskrigen. Etter krigen hadde Norge og Sovjetunionen nedsatt en felles kommisjon som skulle kartlegge de sovjetiske krigsgravene i Norge. Kommisjonen ble nedsatt i 1946, men etter kort tid ble «russerne mistenkt for å bruke kommisjonens reiser som et påskudd til å besøke militære og industrielle anlegg» (Bones, 2015a, s. 339). De spredte gravstedene lå ofte i nærheten av tyske forsvarsanlegg som Norge tok i bruk etter krigen. Norge fryktet at besøk på gravstedene kunne være et påskudd for sovjetisk etterretning til å ta forsvarsanleggene nærmere i øyesyn. I 1951, etter press fra blant annet forsvarsminister Jens Chr. Hauge, bestemte regjeringen seg for at de sovjetiske krigsfangene som var gravlagt spredt utover Nord-Norge, skulle samles og flyttes til en felles krigskirkegård på øya Tjøtta i Nordland (Bones, 2015a; Fjermeros, 2013; Rønnebu, 2014). Sikkerhetspolitikken kom her i første rekke, selv om også internasjonale konvensjoner og praktiske hensyn tilsa at det var naturlig å samle levningene $i$ en felles krigskirkegård (Bones, 2015b, s. 148).

Prosjektet ble kalt Operasjon asfalt, ettersom levningene skulle fraktes i asfaltsekker. Operasjonen ble gjenstand for skarp kritikk fra Sovjetunionen, men også i Norge var det flere som var kritiske til måten den ble gjennomført på (Soleim, 2016). Kommunister i Norge hevdet at den norske regjeringen «ville legge et glemselens slør over de falne sovjetiske soldatene» (Bones, 2015a, s. 339). Ikke bare skulle levningene graves opp og flyttes, minnesmerkene som var reist ved de opprinnelige gravstedene skulle også fjernes. Likene ble gravd opp med gravemaskiner og ullteppene

\footnotetext{
${ }^{13}$ "Seiersmonumentet blir "dempet ned»», VG, 23.8.1951, RA/S-2259/Dz/L0484/Doss 8.6.15, Bd. II.

${ }^{14}$ Moskva til UD, 12.9.1951, RA/S-2259/Dz/L0484/Doss 8.6.15, Bd. II.

${ }^{15}$ Notat, 8.10.1951, RA/S-2259/Dz/L0484/Doss 8.6.15, Bd. II.
} 
eller presenningene de var gravlagte i måtte av hygieniske årsaker brennes. I tillegg ble det ofte brukt sprengstoff for å fjerne minnesmerkene som var reist ved flere av gravstedene. Sovjetunionen "protesterte heftig» mot operasjonen, og hevdet at hele prosessen var regelrett gravskjending (Soleim, 2016, s. 141).

Operasjonen var omdiskutert mens den pågikk, og har fortsatt å være kontroversiell. Den var på mange måter en test på hvordan Norge skulle forholde seg til at Sovjetunionen var en alliert under verdenskrigen, men en fiende i den kalde krigen. Operasjonen var også en illustrasjon på forbindelsene mellom norsk sikkerhetspolitikk og det offisielle norske minnet om Sovjetunionens innsats under krigen. Steinar Aas hevder at norsk minnepolitikk overfor Sovjetunionen gikk fra «allianse til antagonisme» i denne perioden (Aas, 2012, s. 227). Stian Bones har imidlertid betegnet det som et «brudd på det som i et lengre perspektiv ble normalen», nemlig at myndighetene i tiden etter 1951 erkjente at Norge måtte anerkjenne den sovjetiske innsatsen i den felles kampen mot Tyskland for å bevare et levelig naboskap med Sovjetunionen (Bones, 2015a, s. 343, 2015b, s. 148-149).

Anklagene om at de sovjetiske levningene ble uverdig behandlet, var naturlig nok ektefølt, og fra Moskva kunne den norske ambassaden melde om at «de friserte rapportene om angivelig gravskjending gjorde inntrykk [på den jevne befolkning i Moskva]». ${ }^{16}$ Imidlertid ble Operasjon asfalt av sovjetiske myndigheter også brukt som en inngang til å kritisere Norges integrasjon i Nato. Kritikken i media var «en klar beskjed til Norge» om at det var sikkerhetspolitisk «risikabelt å knytte seg for tett til USA" (Bones, 2015b, s. 148). Arbeidet med Frigjøringsmonumentet involverte ikke levninger og var i utgangspunktet ikke like kontroversielt, men endringene ble likevel fremstilt som enda et eksempel på at norske myndigheter hånte den sovjetiske innsatsen. De sovjetiske reaksjonene resonerte også i enkelte kretser i Norge. Avisa Friheten hevdet at monumentet ville være «lite tilfredsstillende» og «kunstnerisk meningsløst» (Friheten, 1952). Avisa var sterkt kritisk til endringene, og levnet liten tvil om at det handlet om Norges forhold til Nato:

Som det nå er, står altså monumentet der ikke som et uttrykk for den naturlige takknemmelighet det norske folk føler for den krigsmakt som bar de tyngste byrdene under krigen mot hitlerfascismen og som var den første til å frigjøre norsk territorium, men som en skamstøtte over den norske sosialdemokratiske regjering, som først bestemte å reise monumentet, men siden ga ordre om at det for all del ikke måtte virke sårende på de tyske imperialistene og som endelig ikke vet sin arme råd hvordan de skal få avduket det under sømmelige former uten samtidig å tråkke sine amerikanske overherrer for mye på tærne. (Friheten, 1952)

Heller ikke kritikken fra Sovjetunionen avtok med det første. I slutten av mars 1952 rapporterte den norske ambassaden i Moskva at den sovjetiske avisa Literaturnaja Gazeta hadde publisert en lang artikkel om monumentet i Kirkenes. Avisa skrev at de russiske soldatene hadde "uselvisk og oppofrende» reddet sivilbefolkningen «fra

${ }^{16} 231$ Moskva til UD, 31.3.1952, RA/S-2259/Dz/L0484/Doss 8.6.15, Bd. II. 
den visse død ved å skaffe husly, mat og legehjelp». Det planlagte monumentet var blitt møtt med bred støtte, og selv Kong Haakon hadde, etter avisas utsagn, uttalt at «Sovjet-Samveldet [hadde] vært en avgjørende faktor i demokratiets kamp mot hitlerbarbariet». Endringene på monumentet hadde ifølge den russiske avisa blitt gjennomført fordi «de herskende i Norge innledet forhandlinger om Norges tilslutning til den aggressive nordatlantiske blokk». ${ }^{17}$ Ifølge avisa var det den kalde krigen som hadde gjort at norske myndigheter nå gjorde skam på minnet om de sovjetiske soldatene:

Under ledelse av utenlandske militære eksperter var det flyplasser og ikke monumenter som ble gjort ferdig i Nord-Norge for amerikanske bombefly og dessuten flåtebaser, militærbrakker og strategiske veier. I samsvar med dette endret tonene seg i den norske borgerlige pressen. Mens de herskende kretser i Norge i de første årene etter krigen hadde lagt skjul på sitt fiendskap mot Sovjet-Samveldet og hadde talt om Samveldet som frigjøreren og den gode naboen, fikk stemmene nå en mer oppriktig klang. ${ }^{18}$

Artikkelen ga tydelig uttrykk for at inskripsjonen på monumentet hadde blitt endret «så den 'ikke ble altfor provokatorisk' overfor Hitler-Tyskland. For ellers ville - Gud trøste oss - hitleristene - ennå med våpen $\mathrm{i}$ hånd - og Bonns nyfascister bli fornærmet!». I samme artikkel ble det spekulert i om monumentet noensinne ville bli avduket: «I nesten et år nå står den lemlestede og omformede statuen gjemt under en striesekk som blafrer i vinden. [...] Hvordan kan man [avduke statuen], hvis de som nå styrer i Norge er yankees, hvis man nå er alliert med hitlerister [VestTyskland]?», spurte skribenten A. Kornilov retorisk. Kanskje planla Norge i hemmelighet å tilintetgjøre hele monumentet, spekulerte han, slik man året før hadde valgt å flytte graver med sovjetiske soldater som falt på norsk jord fra grenseområdet mot Sovjetunionen til øya Tjøtta i Nordland. Dette var tydelige uttrykk for den sovjetiske skuffelsen over utviklingen i norsk sikkerhetspolitikk, som man mente foregikk under sterkt ideologisk påtrykk vestfra. ${ }^{19}$

Den norske ambassaden i Moskva kommenterte at det var «unektelig trist at den utsatte avsløring av minnesmerket i Kirkenes skal kunne gi påskudd til ny kritikk av de norske myndigheters opptreden». ${ }^{20}$ Utenriksdepartementet svarte ambassaden at utsettelsen av avdukingen av monumentet ble gjort "[p]å grunn av de klimatiske forhold», at det ikke var forutsigbart å reise med fly til Kirkenes så sent på høsten. Det var kanskje ikke helt usant, men utsettelsen handlet også om å forsikre seg om at Frigjøringsmonumentet ikke skulle tjene som springbrett for sovjetisk kritikk av Norges sikkerhetspolitikk. Departementet kommenterte nemlig også at det burde avdukes når de politiske forhold var gunstigere. ${ }^{21}$

${ }^{17} 230$ Moskva til UD, 31.3.1952, RA/S-2259/Dz/L0484/Doss 8.6.15, Bd. II.

${ }_{18} 230$ Moskva til UD, 31.3.1952, RA/S-2259/Dz/L0484/Doss 8.6.15, Bd. II.

${ }^{19} 230$ Moskva til UD, 31.3.1952, RA/S-2259/Dz/L0484/Doss 8.6.15, Bd. II.

${ }^{20} 231$ Moskva til UD, 31.3.1952, RA/S-2259/Dz/L0484/Doss 8.6.15, Bd. II.

${ }^{21} 245$ UD til Moskva, 8.4.1952, RA/S-2259/Dz/L0484/Doss 8.6.15, Bd. II. 


\section{Avduking}

Først ett år senere sendte UD invitasjon til fire delegater fra den sovjetiske ambassaden til en offisiell lunsj og den seremonielle avdukingen av monumentet. ${ }^{22}$ Ett år i forkant, og før de sovjetiske reaksjonene, hadde det opprinnelig vært meningen at samferdselsminister Nils Langhelle skulle foreta avdukingen på Utenriksdepartementets vegne. ${ }^{23}$ Etter kontroversen hadde UD landet på at en mindre markering var å foretrekke, og Peder Holt, fylkesmannen i Finnmark, ble utpekt til å være vertskap for høytideligheten. I utkastet til talen som Holt skulle holde under avdukingen, stod det at "Gleden over frigjøringen var kanskje hos enkelte nordmenn blandet sammen med en aldri så liten engstelse. Vi var gla [sic] vi var kvitt tyskerne, men ville de sovjetiske tropper som rykket inn i Sør-Varanger være befriere, eller var kanskje de også erobrere?». ${ }^{24}$ Denne passasjen er imidlertid strøket over med blyant i dokumentet som befinner seg i UDs arkiv. Norske myndigheter hadde - gjennom sju års arbeid med Frigiøringsmonumentet - funnet ut at det var i lavspenningens interesse å holde de sikkerhetspolitiske diskusjonene utenfor det offisielle minnet om Sovjetunionens innsats under krigen.

Holt skulle også avslutte sin tale med å «be dere alle reise dere til ære for de tapre sovjetiske soldater som frigjorde Kirkenes i 1944», men også denne setningen var endret. Begrepet frigjorde er strøket over og erstattet med "falt i Kirkenes». ${ }^{25}$ Dette var enda et eksempel på at Norge ikke ville forkludre Frigjøringsmonumentet med sikkerhetspolitikk: Det var mindre kontroversielt å minnes de som mistet livet. Mulighetsrommet for å bruke avdukingen til å diskutere de store sikkerhetspolitiske spørsmålene ble på denne måten innsnevret.

Datoen for avdukingen, 8. juni 1952, hadde ingen som helst klar referanse til hendelser i Finnmark åtte år tidligere. Det var likevel knyttet stor spenning til det som skulle bli den første fysiske prøven på norsk minnepolitikk overfor Sovjetunionen etter Norges tilslutning til Nato. Og det var flere tegn til at Sovjetunionen hadde sine egne minnepolitiske målsetninger for seremonien og for monumentet. Fjodor Mikhailov, den sovjetiske ambassaderåden, fremstilte Sovjetunionens innsats som en befrielsesoperasjon, og uttalte i sin tale at de sovjetiske soldatene «befridde Kirkenes og Finnmark for øvrig fra de fascistiske erobrere». ${ }^{26}$ Den Røde armés soldater «la dermed grunnen for frigjøringen av hele Norge fra de tyske okkupantene», erklærte han. ${ }^{27}$ Mikhailov fortsatte med å understreke at Sovjetunionen hadde vist «sin store

\footnotetext{
${ }^{22}$ Notat, 8.5.1952, RA/S-2259/Dz/L0484/Doss 8.6.15, Bd. II.

${ }^{23}$ UD til Kirke- og undervisningsdepartementet, 22.6.1951, RA/S-2259/Dz/L0484/Doss 8.6.15, Bd. II.

${ }^{24}$ Råutkast, udatert, RA/S-2259/Dz/L0484/Doss 8.6.15, Bd. II.

${ }^{25}$ Råutkast, udatert, RA/S-2259/Dz/L0484/Doss 8.6.15, Bd. II.

${ }^{26}$ Mikhailovs tale, 8.6.1952, RA/S-2259/Dz/L0484/Doss 8.6.15, Bd. II. Dokumentet er en oversettelse av talen.

${ }^{27}$ Mikhailovs tale, 8.6.1952, RA/S-2259/Dz/L0484/Doss 8.6.15, Bd. II.
} 
respekt for det norske folkets suverene rettigheter og dets nasjonale og statlige tradisjoner» da kampene var over. ${ }^{28}$ Mikhailov understreket til slutt at Sovjetunionen aldri hadde hatt andre ambisjoner for Norge enn å frigjøre det: «Og da de tysk-fascistiske troppene var endelig knust, [...] og sovjettroppene hadde fullført sin frigjøringsmisjon i Norge, trakk de seg, i samsvar med ordre fra sovjetregjeringen, ut fra Deres land, som de var kommet til unnsetning i en tung tid». ${ }^{29}$

Her fremstilte Mikhailov det som om Finnmarks frigjøring hadde vært et mål for Sovjetunionen. Realitetene var annerledes. Den sovjetiske innmarsjen hadde blitt taktisk og strategisk nødvendig for å sikre den sovjetiske fremrykningen på Nordkalotten, og det hadde aldri vært noe vedtatt mål om å frigiøre sivilbefolkningen eller å giøre krav på landområder i Finnmark (Eriksen \& Halvorsen, 1987, s. 34; Holtsmark, 2015d, s. 33). Sovjetiske soldater hadde heller aldri vært lenger vest enn Tana, og hadde dermed ikke deltatt i frigjøringen av de vestlige delene av fylket - slik Mikhailov antydet. Ved å legge så stor vekt på frigjøringen, fremstod Sovjetunionen som den ubestridte helten, og under de mange kommende minnemarkeringene $\mathrm{i}$ Kirkenes under den kalde krigen søkte norske myndigheter å minne også om den norske innsatsen (Myklebost \& Markussen, 2021).

Mikhailov avsluttet med å uttale at «Da sovjetfolket seierrikt hadde avsluttet krigen og befridd Europas folk fra det fascistiske slaveri, tok det fatt på sitt fredelige arbeid, og det løser fremgangsrikt den historiske oppgave: å bygge det kommunistiske samfunn». ${ }^{30}$ Setningen "seierrikt hadde avsluttet krigen og befridd» er understreket med rød penn i en oversettelse som ligger i Utenriksdepartementets arkiv. ${ }^{31}$ Mikhailovs formulering vakte tilsynelatende oppsikt i departementet. Holt, på sin side, benyttet sin taletid til å understreke at den «norske regjering nærer et innerlig [sic] ønske om at der i all fremtid må herske fred og forståelse mellom Norge og Sovjet-Samveldet». ${ }^{32}$ Holt avsluttet med å videreformidle at regjeringen «håper at det monument som nå skal avdukes må stå i all fremtid ikke bare som et minnesmerke om tapre krigere, men også som et symbol på godt naboforhold mellom Norge og vår store nabo i øst». ${ }^{33} \mathrm{Holt}$ gjorde det med andre ord helt eksplisitt at Frigjøringsmonumentet - fra norsk side i alle fall - var et redskap for å bevare gode relasjoner med Sovjetunionen.

To år senere ble det arrangert tiårsmarkering for frigjøringen av Finnmark. Justisminister Gustav Sjaastad representerte regjeringen ved det som skulle bli den eneste

\footnotetext{
${ }^{28}$ Mikhailovs tale, 8.6.1952, RA/S-2259/Dz/L0484/Doss 8.6.15, Bd. II.

${ }^{29}$ Mikhailovs tale, 8.6.1952, RA/S-2259/Dz/L0484/Doss 8.6.15, Bd. II.

${ }^{30}$ Mikhailovs tale, 8.6.1952, RA/S-2259/Dz/L0484/Doss 8.6.15, Bd. II.

${ }^{31}$ Mikhailovs tale, 8.6.1952, RA/S-2259/Dz/L0484/Doss 8.6.15, Bd. II.

${ }^{32}$ Holts tale, udatert, 1952, RA/S-2259/Dz/L0484/Doss 8.6.15, Bd. II.

${ }^{33}$ Holts tale, udatert, 1952, RA/S-2259/Dz/L0484/Doss 8.6.15, Bd. II.
} 
gangen under den kalde krigen at en norsk statsråd deltok i et slikt arrangement i Kirkenes. Gjennom de påfølgende tiårene strevde Norge med å tøyle sovjetiske ønsker om storstilte felles minnemarkeringer ved Frigjøringsmonumentet (Myklebost \& Markussen, 2021 ). Likevel ble det tydelig at Norge hadde lyktes med å etablere et offisielt minne om den sovjetiske innsatsen som sørget for å holde spenningsnivået lavt. I 1954 så det også ut til at Sovjetunionen delte interessen for et rolig og fredfullt grenseområde. Det sovjetiske forsvarsministeriet skrev i en pressemelding etter markeringen at «Feiringen av den bemerkelsesverdige dato - 10 årsdagen for befrielsen av Nord-Norge av sovjetiske tropper - tjener utvilsomt til å utvikle videre de vennskapelige forbindelser mellom Norge og Sovjet-Samveldet». ${ }^{34}$ Den sovjetiske delegasjonen som hadde deltatt i seremonien i Kirkenes hadde «vært meget tilfreds med besøket». ${ }^{35}$

\section{Konklusjon}

Til tross for de mange utfordringene, endringene og tiden som hadde gått med, var avdukingen av Frigjøringsmonumentet en suksess sett med norske utenrikspolitiske øyne. UD klarte å balansere sikkerhetspolitiske og minnepolitiske hensyn på en måte som tilfredsstilte alle parter. Sovjetunionen kunne leve med det nedskalerte monumentet, kanskje nettopp fordi de ble fremstilt som frigjørere, og Norge hadde sikret at fortellingen ikke inneholdt for mye anti-tysk symbolikk. Ikke minst hadde Norge, kanskje uten å være klar over det der og da, skapt et offisielt minne om den sovjetiske frigjøringen som kunne tjene de sikkerhetspolitiske målsetningene om lavspenning $\mathrm{i}$ forholdet til Sovjetunionen.

Forutsetningen for suksessen til det offisielle norske minnet ligger i de historiske realitetene. Sovjetiske styrker frigjorde faktisk Øst-Finnmark fra tyskernes okkupasjon og trakk seg dernest ut av området da krigen var over. Dette gjorde at sovjetiske myndigheter rettmessig kunne forvente norske myndigheters takknemlighet. Denne artikkelen har vist at Norge ikke trengte noen oppfordring for å utvise takknemlighet gjennom et monument. Som vi har sett ble det ansett som et privilegium å reise det, og til tross for kontroversene som utspilte seg før monumentet ble avduket, er det ingenting $\mathrm{i}$ arkivmaterialet som tyder på at det på noe som helst tidspunkt ble vurdert å skrinlegge prosjektet. Den norske interessen for et slikt monument kan forklares med at norske myndigheter i årene 1945-1952 ble oppmerksomme på at monumentet kunne spille en viktig sikkerhetspolitisk funksjon. I sin tur er det en viktig forklaring på at Frigjøringsmonumentet -i motsetning til lignende monumenter i Sentral- og Øst-Europa - ikke har blitt gjenstand for kontroverser eller bilaterale konflikter, men i stedet en arena for dialog.

\footnotetext{
${ }^{34}$ Moskva til UD, 26.10.1954, RA/S-2259/Dz/L0484/Doss 8.6.15B, Bd. I.

${ }^{35}$ Moskva til UD, 2.11.1954, RA/S-2259/Dz/L0484/Doss 8.6.15B, Bd. I.
} 


\section{4 | JOAKIM AALMEN MARKUSSEN}

Gjennom hele prosessen med å opprette Frigiøringsmonumentet i Kirkenes virket både de kollektive minnene om den sovjetiske frigjøringen av Finnmark inn i det sikkerhetspolitiske bildet - og vice versa. I løpet av de sju årene som prosessen pågikk, erkjente Norge at det å ha en ukontroversiell arena å møte Sovjetunionen på, var et sikkerhetspolitisk mål i seg selv. Når Nato-medlemskapet gjorde det vanskelig å utøve en troverdig brobyggingspolitikk, var det nyttig med et pustehull i jernteppet som senket seg over Europa. I prosessen med å reise Frigjøringsmonumentet ble det offisielle norske minnet om Sovjetunionens frigjøring i Finnmark et viktig redskap, og en avgjørende døråpner for dialogen som kom til å prege forholdet mellom Norge og Sovjetunionen gjennom den kalde krigen.

Samtidig ble det kollektive minnet preget av det sikkerhetspolitiske klimaet. Norges beslutninger om å sende fylkesmannen i Finnmark til avdukingen, og ikke en statsråd, viser - selv om det ikke ble eksplisitt formulert - at det var en viktig målsetning å sørge for et rolig grenseområde med minimalt spenningsnivå. For å realisere dette sikkerhetspolitiske målet var Norge best tjent med å innsnevre mulighetene for politiske diskusjoner. Selv om minnet om de sovjetiske frigjørerne ikke alltid passet inn i norsk sikkerhetspolitikk, tjente Frigiøringsmonumentet i Kirkenes likevel en viktig sikkerhetspolitisk funksjon ved at de kollektive minnene som ble forankret $\mathrm{i}$ det, bidro til at Sovjetunionen ikke utelukkende kunne fremstilles som en ubetinget trussel. Monumentet var en påminnelse om at Norges forhold til Sovjetunionen ikke alltid hadde vært preget av fiendskap, og la dermed grunnlaget for en minnediplomatisk dialog med Sovjetunionen som kom til å vare gjennom hele den kalde krigen og frem til i dag.

\section{Litteratur}

Assmann, A. (2006). Memory, individual and collective. I R. E. Goodin \& C. Tilly (red.), The Oxford handbook of contextual political analysis (s. 210-224). Oxford University Press.

Bones, S. (2006). Med viten og vilje. Nytt Norsk Tidsskrift, 23(3), 276-284.

Bones, S. (2015a). Kald krig. I S. G. Holtsmark (red.), Naboer i frykt og forventning (s. 314-343). Pax.

Bones, S. (2015b). Krig, frigjøring og minne. I F. Fagertun (red.), Krig og frigjøring i nord (s. 143-152). Orkana akademisk.

Ehala, M. (2009). The bronze soldier: Identity threat and maintenance in Estonia. Fournal of Baltic Studies, 40(1), 139-158. https://doi.org/10.1080/01629770902722294

Eriksen, K. E. (1972). DNA og NATO. Gyldendal.

Eriksen, K. E. \& Halvorsen, T. (1987). Frigjøring. Aschehoug.

Erll, A. \& Young, S. B. (2011). Memory in culture. Palgrave Macmillan.

Fjermeros, H. (2013). Med lik i lasten. Scandinavian Academic Press.

Folkenborg, H. R. (2019, 24. juli). Derfor ble den tyske riksørnen fjernet fra et norsk krigsmonument [Kronikk]. Aftenposten. https://www.aftenposten.no/meninger/kronikk/i/jdgLMe/derfor-ble-den-tyskeriksoernenfjernet-fra-et-norsk-krigsmonument-haa

Friheten. (1951, 22. februar). Monumentet på Kirkenes ferdig på forsommeren.

Friheten. (1952, 4. mars). Hvorfor er sovjet-monumentet på Kirkenes ennå ikke reist?

Gabowitsch, M. (2014). Soviet war memorials: A few biographical remarks. Chto delat', 37, 6-8.

Gegner, M. (2012). War monuments in East and West Berlin: Cold War symbols or different forms of memorial? I M. Gegner \& B. Ziino (red.), The heritage of war (s. 64-87). Routledge.

Hilde, P. S. (2019). Forsvar vår dyd, men kom oss ikke for nær. Norge og det militære samarbeidet i NATO. Internasjonal Politikk, 77(1), 60-70. https://doi.org/10.23865/intpol.v77.1626 
Holst, J. J. (1967). Norsk sikkerhetspolitikk i strategisk perspektiv. Norsk utenrikspolitisk institutt.

Holtsmark, S. G. (2015a). Krig og allianse. I S. G. Holtsmark (red.), Naboer i frykt og forventning: Norge og Russland 1917-2014 (s. 227-279). Pax.

Holtsmark, S. G. (2015b). Brobygging og sovjetiske framstøt. I S. G. Holtsmark (red.), Naboer $i$ frykt og forventning: Norge og Russland 1917-2014 (s. 280-303). Pax.

Holtsmark, S. G. (2015c). Veien mot Atlanterhavspakten. I S. G. Holtsmark (red.), Naboer i frykt og forventing: Norge og Russland 1917-2014 (s. 304-313). Pax.

Holtsmark, S. G. (2015d). Om den Røde hær rykker inn i Norge ... Spørsmålet om sovjetisk deltagelse i frigjøringen av Norge 1941-1944. I F. Fagertun (red.), Krig og frigjøring $i$ nord. (s. 11-24). Orkana akademisk.

Holtsmark, S. G. (red.). (2015e). Naboer i frykt og forventning: Norge og Russland 1917-2014. Pax.

Kalashnikov, A. (2018, 20. august). Soviet war memorials in Eastern Europe continue to strain relations with Russia. The Conversation. https:/theconversation.com/soviet-war-memorials-in-eastern-europecontinue-to-strain-relations-with-russia-101687

Karlsson, K. G. (2004) Historiedidaktik: Begrepp, teori och analys. I K. G. Karlsson \& U. Sander (red.), Historien är nu: en introduktion till historiedidaktiken (s. 21-66). Studentlitteratur.

Koposov, N. (2018). Memory laws, memory wars: The politics of the past in Europe and Russia. Cambridge University Press.

Kriza, E. (2019). The Stalin plaque in Vienna: Hiding and showing history. European Review of History, 26(3), 409-427. https://doi.org/10.1080/13507486.2018.1505832

Lippe, J. (red.). (1964). Finnmark fritt! Erindringer fra frigjøringskampene mot Hitler armeen i nord. Ny Dag.

Markussen, J. A. (2020). Krigshistoriens livslop: Samspillet, konkurransene og kampene om iscenesettelsen av NordNorges krigshistorie [Doktorgradsavhandling, UiT Norges arktiske universitet]. UiT Munin. https://hdl. handle.net/10037/19771

Miller, A. (2020). Russia and Europe in memory wars (NUPI Working Paper 887). Norwegian Institute of International Affairs.

Morgenbladet. (1951, 14. juni). Kjempemessig russisk monument i Kirkenes.

Myklebost, K. A. \& Markussen, J. A. (2021). Dragkamp og balansegang: Frigjøringsmarkeringene på Kirkenes 1954-1994. Nordisk Østforum, 35, 60-79. https://doi.org/10.23865/noros.v35.2604

Mälksoo, M. (2015). 'Memory must be defended': Beyond the politics of mnemonical security. Security Dialogue, 46(3), 221-237. https://doi.org/10.1177/0967010614552549

Olick, J. K. \& Robbins, J. (1998). Social memory studies: From 'collective memory' to the historical sociology of mnemonic practices. Annual Review of Sociology, 24(1), 105-140. https://doi.org/10.1146/annurev. soc. 24.1 .105

Olsen, B. W. (2014, 21. oktober). Slik fikk sovjetsoldaten den unaturlige kroppsholdningen. Sør-Varanger avis.

Poole, R. (2008). Memory, responsibility, and identity. Social Research, 75(1), 263-286.

Rowe, L. (2018). Fornuft og følelser: Norge og Russland etter Krim. Nordisk Østforum, 32. https://doi.org/ 10.23865/noros.v32.1037

Rønnebu, G. L. (2014). «En ualminnelig vemmelig sak»: Operasjon Asfalt 1951. Heimen, 51, 1-20(4), 343-354.

Scharffenberg. (1951, 14. juni). Hakekorset - ikke Riksørnen. Morgenbladet.

Skogrand, K. (2004). Alliert $i$ krig og fred. Eide.

Soleim, M. N. (2016). "Operasjon asfalt»: Kald krig om krigsgraver. Orkana akademisk.

Stangl, P. (2010). The Soviet war memorial in Treptow, Berlin. Geographical Review, 93(2), $213-236$. https://doi.org/10.1111/j.1931-0846.2003.tb00030.x

Tamm, M. (2013). Beyond history and memory: New perspectives in memory studies. History Compass, 11(6), 458-473. https://doi.org/10.1111/hic3.12050

Tamnes, R. (1987). Svalbard mellom øst og vest. Forsvarshistorisk forskningssenter.

Tjelmeland, H. (2015). Andre verdskrig og oppkomsten av norsk brubyggingspolitikk. I F. Fagertun (red.), Krig og frigjøring $i$ nord (s. 51-60). Orkana akademisk.

Tjelmeland, H. (2017). Arbeidarpartiet, bolsjevikpartiet og sovjetstaten 1917-1991. Arbeiderhistorie, 21(1), 85-105. https://doi.org/10.18261/issn.2387-5879-2017-01-06

Torbakov, I. (2011). History, memory and national identity: Understanding politics of history and memory wars in post-Soviet lands. Demokratizatsiya, 19(3), 209-232.

Verdens Gang. (1945a, 5. juli). Befrielsesmonumentet i Kirkenes blir 11 meter høyt.

Verdens Gang. (1945b, 2. juli). Monument i Kirkenes.

Verdens Gang. (1945c, 24. august). Sovjetrussisk soldat i bronse av Stinius Fredriksen. 


\section{JOAKIM AALMEN MARKUSSEN}

Winge, L. (2019, 29. oktober) Beklager til partisanene, medaljer til veteranene. Sør-Varanger avis.

Winter, J. (2006). Remembering war: The great war between memory and history in the 20th Century. Yale University Press.

Zhurzhenko, T. (2018). The Soviet war memorial in Vienna: Geopolitics and the new Russian diaspora in postCold War Europe. I P. Finney (red.), Remembering the Second World War (s. 89-114). Routledge.

Aas, S. (2012). Norwegian and Soviet/Russian World War II memory policy during the Cold War and the postSoviet years. Acta Borealia, 29(2), 216-239. https://doi.org/10.1080/08003831.2012.678721

\section{Arkivmateriale}

Riksarkivet. S-1021 - Kirke- og undervisningsdepartementet. 1. skolekontor D. Serie E, Ej, stykke L0700, mappe 0004 Kirkenesmonumentet for frigjøringen.

Riksarkivet. S-2259 - Utenriksdepartementet. Serie DyD, stykke L10082, mappe Doss 8.6.15 Bd 1.

Riksarkivet. S-2259 -Utenriksdepartementet. Serie Dz stykke L0484, mappe Doss 8.6.15, Bd. II. 